International Journal of Technology 11(4) 710-721 (2020)

Received April 2020 / Revised April 2020 / Accepted May 2020

International Journal of Technology

http://ijtech.eng.ui.ac.id

\title{
Revisited the Technology Acceptance Model with E-Trust for Peer-to-Peer Lending in Indonesia (Perspective from Fintech Users)
}

\author{
Sevenpri Candra ${ }^{*}$, Fauziyah Nuruttarwiyah ${ }^{2}$, Indri Hanung Hapsari² \\ 1Management Department, BINUS Business School Master Program, Bina Nusantara University, Jakarta \\ 11480, Indonesia \\ ${ }^{2}$ Management Department, BINUS Online Learning, Bina Nusantara University, Jakarta 11480, Indonesia
}

\begin{abstract}
The rapid increase in the number of fintech companies in Indonesia in the past three years has attracted the attention of many stakeholders, including the government, investors, conventional bank management, and even the general public. The phenomenon of the development of peer-topeer lending fintech companies in Indonesia is supported by the increasing demand of consumers. The research objective is to provide insight into the determinants of consumer interest in using fintech applications, using the technology acceptance model by added e-trust variables . The data analysis method used structural equation modeling with WarpPLS 6.0 software. Questionnaires were distributed to fintech consumers in Indonesia, with a total sample of 379 respondents. The results of this study indicate that the dimensions of e-trust contribute to determining the perceived usefulness, perceived ease of use, attitude to adopt peer-to-peer lending fintech services, and intention to use peer-to-peer lending applications.
\end{abstract}

Keywords: Attitude; E-trust; Intention to use; Perceived ease of use; Perceived usefulness

\section{Introduction}

The term fintech is an abbreviation of the words "financial" and "technology " that means an innovation in the field of financial services that combines technology and financial service activities (Schueffel, 2016; Ketterer, 2017). Fintech is a new sector in the financial industry that combines various technologies to support trade, corporate business, and services to retail consumers (Gibson, 2015; Micu and Micu, 2016; Temelkov, 2018). It has been very popular in various countries in the last ten years (Arner et al., 2015; Prawirasasra, 2018; KPMG, 2018; Jünger and Mietzner, 2019). Indonesia has great potential for the development of fintech. With a population of around 250 million and gross domestic product in the first quarter of 2018 reached IDR 3,505.3 trillion (Badan Pusat Statistik, 2018). Fintech is one of product that born in the digital era and this is innovation for financial industry (Berawi, 2014; Accenture, 2019). This can be seen from the popularity of fintech in Indonesia, which is in line with the increasing use of internet services and number of smartphone users. However, the results of Sjamsudin's study (2019) show that the market share of fintech in the financial services sector is still relatively small compared to the market share of banks. But, the rapid increase in the number of fintech companies in Indonesia over the past three years has attracted the attention of many stakeholders,

${ }^{*}$ Corresponding author's email: seven@binus.ac.id, Tel.: +62-8159630770 doi: 10.14716/ijtech.v11i4.4032 
including the government, investors, conventional bank management, and even the general public (Davis et al., 2017; Otoritas Jasa Keuangan, 2017; Dipa, 2018).

Fintech can be divided into four sectors, namely e-payment/e-wallet, crowdfunding and peer-to-peer lending, risk and investment management, and market aggregators (Bank Indonesia, 2017). According to Hadad (2017), fintech in Indonesia increased every year until 2016; there are 165 fintech listed in the Indonesian Fintech Association and Indonesian Government Financial Services Authority (Otoritas Jasa Keuangan, 2017). The most widely developed is fintech for payment systems (e-payment/e-wallet) is $42 \%$, while peer-to-peer lending is18\% (Hadad, 2017; Otoritas Jasa Keuangan, 2017; Dipa, 2018; Duwitmu, 2019; Franedya, 2019; Setyowati, 2019; Sjamsudin, 2019). The role of fintech is expected to provide equal distribution of the welfare of the population in Indonesia, especially by encouraging micro, small, and medium enterprises (KPMG, 2018).

Peer-to-peer lending is a fintech that is suitable for providing limited capital solutions for small and medium enterprises. The total increase in lender account entities in Java, outside Java, and abroad from 2017 to July 2019 was 149.94\% (Otoritas Jasa Keuangan, 2017; AlphaJWCVentures, 2019; Kurniawan et al., 2019). The fintech peer-to-peer lending operating system offers convenience for its users through web-based platforms and smartphone applications (Kurniawan et al., 2019; Suyanto and Kurniawan, 2019). In addition, there were 52 companies using applications on their website or web-based platforms. Peer-to-peer lending offers easy terms, flexible guarantees, and speed of service to borrowers to obtain loans through fintech services with competitive interest rates (Aaron et al., 2017; Hadad, 2017; Nursyirwan, 2018; Sjamsudin, 2019). The average time to process a loan disbursement is between 2- 3 days. Behind the convenience of fintech there are some risks that can be dangerous for users (Xie et al., 2016; Suyanto and Kurniawan, 2019). According to Giudici (2018), investing in peer-to-peer lending has a high risk because peerto-peer platforms have less information about their borrowers, compared to banks, and are less able to handle asymmetric information.

Although peer-to-peer lending services have a variety of risks in their use, several studies have shown an increase in the interest of companies, markets, and the public in using these services (Magee, 2011; Frame and White, 2014; Xie et al., 2016; Prayogo, 2017; Otoritas Jasa Keuangan, 2019; Gozali et al., 2020). The number of fintech service providers continues to increase, and some of the results of previous studies conclude that consumer acceptance is a major determinant of the development of fintech in a country (Agarwal et al., 2009; Ben Mansour, 2016). Referring to Alalwan et al. (2015), Candra (2013), and Suyanto and Kurniawan (2019) has confirmed the results of previous studies that the resistance factor is a major barrier for consumers in adopting technology-based financial services. This study aims to provide information about the factors that influence a prospective customer's acceptance of these services and these findings will help service providers or start-ups in designing appropriate fintech lending promotion strategies so that, in the long run, they can contribute to spurring digital economic growth in Indonesia.

\section{Literature Review}

In this study the technology acceptance model (TAM) was used to measure the level of acceptance and utilization of a consumer technology. The TAM understands that behavioral intention is a significant determinant in the actual use of a system. The TAM also shows that behavioral intention is determined by two important things, namely perceived usefulness and perceived ease of use (Davis, 1989; Taylor and Todd, 1995; Venkatesh and Davis, 1996). Research conducted by Ben Mansour (2016) states that perceived usefulness is the main factor that has a direct impact on intention to use, determines a large proportion of attitude, and mediates the perceived ease of use of behavioral intentions. Therefore, by having a high 
perceived ease of use, the user will also have a high perceived usefulness (Ezzi, 2014). Thus, in this study it is hypothesized that there is an effect of perceived ease of use on perceived usefulness. Based on research conducted by Ezzi (2014), perceived ease of use is related to the extent to which a person believes that using technology will be relatively free from difficulties. Users who see the technology as having high ease of use will most likely try to enjoy the technology. So, the second hypothesis in this study is that there is an effect of perceived ease of use on attitude.

As stated in research (Nui Polatoglu and Ekin, 2001; Zhou, 2011; Ben Mansour, 2016; Santoso et al., 2019), perceived usefulness is defined as the extent to which a person believes that using technology will improve job performance, so users who see the technology as having high use will most likely try to enjoy the technology. Therefore, the third hypothesis in this study is that there is an effect of perceived usefulness on attitude. This finding confirms that perceived usefulness will affect attitude and then influence intention to use, but perceived ease of use is proven to have little effect on attitude and intention to use (Candra, 2013; Hampshire, 2017; Suyanto and Kurniawan, 2019). Thus, it is hypothesized that there is an effect of perceived usefulness on intention to use. Other studies done by Fishbein and Ajzen (1975), Triandis (1980), Zhou (2011), and Alalwan et al. (2018) have concluded that the attitude factor has a positive influence on fintech acceptance. Thus, it is hypothesized that there is an effect of attitude on intention to use.

Lee (2009), Alsajjan and Dennis (2010), Ben Mansour (2016), and Sun and Chi (2019) have concluded that e-trust is the center of online relationships, therefore building e-trust between partners is an effective strategic function to increase high levels of trust. E-trust plays an important role in facilitating knowledge sharing, building long-term relationships, and increasing perceived value, which influences technology adoption (Wang and Emurian, 2005). Thus, creating e-trust makes users more willing to accommodate new technology. In this study it is hypothesized that there is an influence of e-trust on perceived usefulness. Various research (Candra, 2013; Ben Mansour, 2016; Hampshire, 2017), in addition to stating that there is a relationship between e-trust and perceived usefulness, states that when users trust service providers, they are likely to pursue benefits and spend less time monitoring and directly implementing online transactions. Thus, in this study it is hypothesized that there is an e-trust effect on perceived ease of use. Ben Mansour (2016) states that four dimensions of e-trust used in his research are credibility, benevolence, integrity, and orientation to resolving problems. E-trust has an impact on personal trust regarding the ease of use and usefulness of fintech peer-to-peer lending and an influence on attitude toward the use of fintech peer-to-peer lending. Thus, it is hypothesized that there is an influence of e-trust on attitude. In addition to affecting attitude, e-trust will also affect intention to use. Thus, it is hypothesized that there is a significant relationship between e-trust and intention to use.

\section{Methods}

This research model analyzed the factors that influenced users in utilizing technologybased fintech as an alternative funding source. Variable construction measures were made by adapting references from previous studies to ensure the validity of the measurement scale (Davis, 1989; Venkatesh and Davis, 1996; Lee, 2009; Candra, 2013; Ben Mansour, 2016; Alalwan et al., 2018). The framework for this research can be seen in Figure 1.

The data obtained was analyzed using the structural equation modeling (SEM) analysis method, which is one type of multivariate analysis in social science (Smith and LangfieldSmith, 2004; Hair et al., 2010; Kock, 2010). Primary data collection was done through the distribution of structured questionnaires directly to respondents or by filling out 
questionnaires distributed via online survey (Cohen, 2013; Sekaran and Bougie, 2016). Samples were selected using non-probability random sampling with the following criteria: (1) users that already using fintech applications; and (2) living in Indonesia.

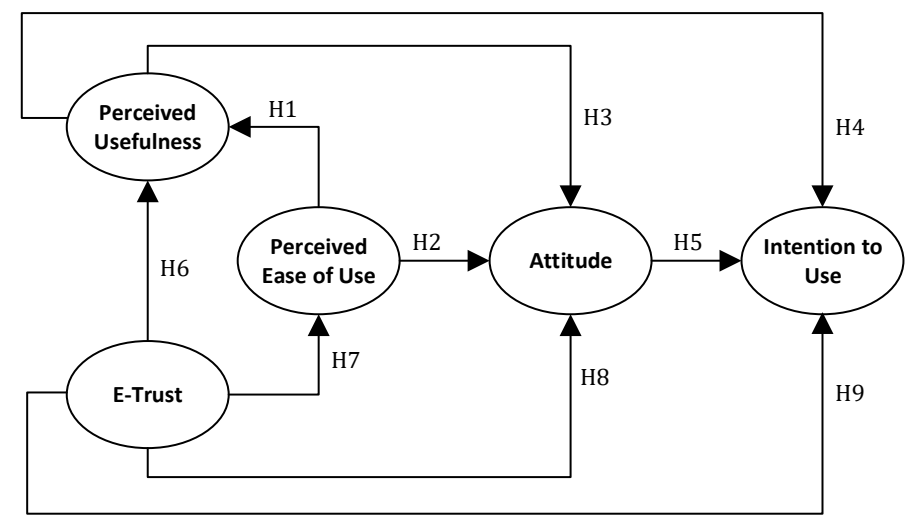

Figure 1 Research model

\section{Results and Discussion}

Based on the collection of obtained questionnaires processed for further analysis there were 379 respondents; Table 1 shows their demographic characteristics. All questionnaire data in this study were analyzed with SEM, in which Warppls was used (Kock, 2010). There are two stages of evaluation in this method, namely the evaluation of measurement models and evaluation of structural models. Based on Warppls software, Measurement model and Structural Model are meet all the all requirements. Evaluation of the measurement model determines the specification of the relationship between latent variables and the indicators therein. Measurement models are tested by conducting validity tests that can be measured by convergent and discriminant validity of the indicators and reliability tests that can be measured by composite reliability and Cronbach's alpha.

Table 1 Demographic characteristics $(n=379)$

\begin{tabular}{|c|c|c|c|c|c|}
\hline Profile Respondents & Frequency & Percentage & Profile Respondents & Frequency & Percentage \\
\hline Age & & & Gender & & \\
\hline $18-25$ & 233 & $61.48 \%$ & Male & 141 & $37.20 \%$ \\
\hline $26-35$ & 99 & $26.12 \%$ & Female & 238 & $62.80 \%$ \\
\hline $36-45$ & 35 & $9.23 \%$ & Expenditures (monthly) & & \\
\hline Over 45 & 12 & $3.17 \%$ & Under IDR 1 million & 36 & $9.50 \%$ \\
\hline Marital Status & & & IDR $1-1.9$ million & 129 & $34.04 \%$ \\
\hline Single & 275 & $72.56 \%$ & IDR 2-2.9 million & 36 & $9.50 \%$ \\
\hline Married & 104 & $27.44 \%$ & IDR 3-3.9 million & 54 & $14.25 \%$ \\
\hline Employment Status & & & IDR 4-5 million & 51 & $13.46 \%$ \\
\hline Working & 188 & $49.60 \%$ & Over 5 million & 73 & $19.26 \%$ \\
\hline Jobless & 191 & $50.40 \%$ & Occupation & & \\
\hline $\begin{array}{c}\text { Education } \\
\text { High }\end{array}$ & & & Private Employee & 124 & $32.72 \%$ \\
\hline School/Diploma & 156 & $41.16 \%$ & Clerical & 7 & $1.85 \%$ \\
\hline Undergraduate & 204 & $53.83 \%$ & Housewife & 21 & $5.54 \%$ \\
\hline \multirow[t]{3}{*}{ Master's Degree } & 19 & $5.01 \%$ & Civil Servant & 17 & $4.49 \%$ \\
\hline & & & Self-Employed & 37 & $9.76 \%$ \\
\hline & & & Other & 173 & $45.65 \%$ \\
\hline
\end{tabular}

Based on Table 2, which displays the results of discriminant validity and reliability, it can be concluded that all indicators met the requirements. Likewise, it is seen based on the 
convergent validity test results that all indicators also met the requirements; the complete results can be seen in Table 3. This research model also met the criteria of the model fit, as shown in Table 4.

Table 2 Discriminant validity test and reliability test

\begin{tabular}{|c|c|c|c|c|c|c|c|}
\hline Variables & Square $\mathrm{F}$ & oots of Ave & rage Vari & ances Extr & acted & $\begin{array}{l}\text { Composite } \\
\text { Reliability }\end{array}$ & $\begin{array}{l}\text { Cronbach's } \\
\text { Alpha }\end{array}$ \\
\hline Perceived Ease of Use & $(0.866)$ & & & & & 0.923 & 0.889 \\
\hline Perceived Usefulness & 0.732 & $(0.806)$ & & & & 0.880 & 0.817 \\
\hline E-Trust & 0.794 & 0.798 & $(0.820)$ & & & 0.968 & 0.965 \\
\hline Attitude & 0.606 & 0.742 & 0.746 & $(0.880)$ & & 0.912 & 0.855 \\
\hline Intention to Use & 0.605 & 0.709 & 0.816 & 0.756 & $(0.868)$ & 0.901 & 0.832 \\
\hline
\end{tabular}

Table 3 Convergent Validity Test

\begin{tabular}{|c|c|}
\hline Variables & Loading Factor \\
\hline \multicolumn{2}{|l|}{ Perceived Ease of Use } \\
\hline There is ease in learning the use of a fintech lending application. & 0.865 \\
\hline It would be very easy for me to be skilled in using a fintech lending application & 0.884 \\
\hline Fintech lending applications are very easy to use. & 0.894 \\
\hline Interaction using a fintech lending application is very clear and easy to understand. & 0.821 \\
\hline \multicolumn{2}{|l|}{ Perceived usefulness } \\
\hline I am very eager to use a fintech lending application. & 0.849 \\
\hline Using a fintech lending application will increase my productivity. & 0.867 \\
\hline Using a fintech lending application will enhance my experience. & 0.791 \\
\hline A fintech lending application is very useful. & 0.704 \\
\hline \multicolumn{2}{|l|}{ E-Trust } \\
\hline In my opinion fintech lending applications are the best solution in the industry. & 0.845 \\
\hline Fintech lending applications, in my opinion, are very efficient. & 0.811 \\
\hline I trust fintech lending applications in that I know they will keep their promises. & 0.856 \\
\hline I trust the information provided by fintech lending applications that I know. & 0.847 \\
\hline I trust fintech lending applications in that I know they will do a good job. & 0.809 \\
\hline $\begin{array}{l}\text { I trust fintech lending applications in that I know they have security features to protect } \\
\text { user data. }\end{array}$ & 0.789 \\
\hline I feel safe putting personal data in a fintech lending application. & 0.840 \\
\hline I am sure I can use a fintech lending application safely. & 0.828 \\
\hline The fintech lending application that I know is very reliable. & 0.841 \\
\hline $\begin{array}{l}\text { Fintech lending applications are continuously improved according to technological } \\
\text { developments. }\end{array}$ & 0.767 \\
\hline In my opinion fintech lending applications always responds to consumer needs. & 0.808 \\
\hline Fintech lending applications have an easy-to-use design. & 0.792 \\
\hline I believe that my fintech lending app always catches my attention. & 0.839 \\
\hline In my opinion fintech lending applications pay attention to consumer issues. & 0.890 \\
\hline If a problem occurs, I'm sure it will be easy to make a complaint. & 0.814 \\
\hline \multicolumn{2}{|l|}{ Attitude } \\
\hline I am very eager to use a fintech lending application. & 0.894 \\
\hline Using a fintech lending application, in my opinion, is a pleasant experience. & 0.872 \\
\hline Using a fintech lending application is a wise idea. & 0.876 \\
\hline \multicolumn{2}{|l|}{ Intention to Use } \\
\hline I wish to use a fintech lending application for loaning funds. & 0.786 \\
\hline If possible, I will use a fintech lending application in business activities. & 0.909 \\
\hline I would advise others to use a fintech lending application. & 0.903 \\
\hline
\end{tabular}

Hypothesis testing can be done by looking at the p-value results, while the path coefficients are used to see the level of significance of the relationship. The accuracy of the hypothesis is obtained by comparing the $p$-value with an alpha (error rate) of $5 \%(\leq 0.05)$. 
Table 4 Model fit indicator results

\begin{tabular}{lll}
\hline Model Fit Indicator & Results & Parameter \\
\hline Average Path Coefficient & $0.399 . \mathrm{p}<.001$ & $\mathrm{p}<.05$, Good \\
Average R-Squared & $0.697, \mathrm{p}<.001$ & $\mathrm{p}<.05$, Good \\
Average Block VIF & 3.062 & $\mathrm{AVIF}<5$, Good \\
Average Adjusted R-Square & $0.696, \mathrm{p}<.001$ & $\mathrm{p}<.05$, Good \\
Average Full Collinearity VIF (AFVIF) & 3.761 & AFVIF $<5$, Good \\
& & $0.1-0.24=$ Small \\
Tenenhaus GoF (GoF) & 0.709 & $0.25-0.35=$ Medium \\
& & GoF $>0.36=$ Large \\
Simpson's Paradox Ratio (SPR) & 1.000 & SPR $>0.7$, Good \\
R-Squared Contribution Ratio (RSCR) & 1.000 & RSCR $>0.9$, Good \\
Statistical Suppression Ratio (SSR) & 1.000 & SSR $>0.7$, Good \\
Nonlinear Bivariate Causality Direction Ratio (NLBCDR) & 1.000 & NLBCDR $>0.7$, Good \\
\hline
\end{tabular}

If the p-value is smaller or equal to alpha, then the hypothesis is accepted, which means that the results of the study are statistically significant (Hair et al., 2010; Kock, 2010). The results of the data processing with WarpPLS can be seen in Table 5, and there was only one hypothesis that did not support this research. Most respondents in this study considered the use of fintech lending applications to be a wise idea because they could improve the effectiveness and productivity of activities. In addition, the use of a fintech lending application was considered to increase, so using fintech lending application was pleasant experience. Moreover, users of fintech lending applications who were accustomed to using e-commerce a lot felt accustomed to virtual transactions, so perceived ease of use was less influential than perceived usefulness.

Table 5 Path coefficients and P-value results

\begin{tabular}{lccc}
\hline Hypotheses & P-Value & Path Coefficients & Decisions \\
\hline Perceived Ease of Use on Perceived Usefulness & $<.001$ & 0.253 & Accepted \\
Perceived Ease of Use on Attitude & .020 & 0.105 & Accepted \\
Perceived usefulness on Attitude & $<.001$ & 0.456 & Accepted \\
Perceived usefulness on Intention to Use & .184 & 0.046 & Not Supported \\
Attitude on Intention to Use & $<.001$ & 0.322 & Accepted \\
E-Trust on Perceived Usefulness & $<.001$ & 0.596 & Accepted \\
E-Trust on Perceived Ease of Use & $<.001$ & 0.808 & Accepted \\
E-Trust on Attitude & $<.001$ & 0.466 & Accepted \\
E-Trust on Intention to Use & $<.001$ & 0.541 & Accepted \\
\hline
\end{tabular}

Factors such as perceived usefulness and perceived ease of use were integrated with e-trust factors as a framework that influences the attitude and intention to use fintech lending applications that focus on the acceptance, expectations, and readiness of Indonesian consumers toward fintech lending application products and services. E-trust plays an important role in facilitating knowledge sharing, building long-term relationships, and increasing perceived value, which influences technology adoption. Thus, creating etrust makes users more willing to accommodate new technology. Because they are interested, the new technology accommodation has a pleasant impact on them.

Most respondents thought that their productivity would be improved because there was ease in learning and using fintech lending applications. This was also supported by easy and clear interactions, making fintech lending applications considered very useful. In addition, users that already have skilled in using a fintech lending application will be improved their experience. Most respondents in this study considered using fintech lending applications a wise idea because there was ease in learning and using them. This was also 
supported by easy and clear interactions that made respondents want to use them. In addition, Users will easily be skilled in using a fintech lending application made it a pleasant experience.

In this study perceived usefulness did not affect the intention to use. Most respondents despite knowing that the application fintech lending offers effectiveness and productivity better. There were still doubts about using it for lending funds or suggesting it to others. In addition, most respondents thought that fintech lending applications were not very useful and were inadequate in their experience.

Most respondents said they would use fintech lending applications in business activities because the use of fintech lending applications was a wise idea. This was also supported by the desire of respondents to use the fintech lending application because it increased their experience in using fintech lending application. Respondents would also suggest to others to use the fintech lending application and even wished to borrow funds through it.

Furthermore, we found that the four dimensions of e-trust-integrity, credibility, benevolence, and orientation-resolved problems having a stronger influence on intention to use compared to perceived usefulness in the context of the adoption of fintech lending applications. Thus, creating e-trust made users more willing to accommodate new technology. In line with previous studies, most respondents in this study assumed that their effectiveness and productivity would be good because fintech lending applications were considered very efficient, known to be very safe and reliable, had a concern for consumers, and were continuously improved according to technological developments.

To overcome the failure of e-trust in this industry, fintech lending professionals can hold educational activities, such as training courses and promotions, that initiate the use of various fintech lending applications to increase user familiarity, transparency, and integrity. In addition, fintech lending companies must also consider user concerns by implementing measures to protect client assets and information, such as process and password authentication, and by providing information about the security of fintech lending applications, unconditional compensation guarantees, and customer service that is easily accessible and educates users. This education is expected to form trust and can facilitate users' operation of a fintech lending application. As concluded in this study, e-trust has an influence on perceived ease of use. As can be seen from the conclusions obtained from the majority of respondents in this study, there was ease in learning and using fintech lending applications because fintech lending applications were the best in the industry, very efficient, safe and reliable, continuously improved according to technological developments, and paid attention to consumer problems. This was also supported by the belief that fintech lending applications carried out and kept their promises and duties properly and always responded to the needs of consumers, and if problems occurred, it was easy to make complaints. In addition, the easy design that easy to use and security features that explain security in storing personal data that make the respondent's belief. A better fintech lending application company is one that can instill trust in users and educate them about the use of the application and services provided so that users can easily operate an application for the achievement of their expected goals. A fintech lending company must also pay extra attention to prevent users from experiencing difficulties in access, system bottlenecks, connection breaks, service delays, and system damage that will directly reduce user confidence. Fintech lending industry players must strive to create informative interfaces for novice users and provide websites that are easily accessible, with fast downloads, short transaction times, easy interfaces, various financial services tailored to the needs of users, and the benefits users often have for users. 
The fintech lending companies must have a commitment to ensure the security and privacy of user data. In addition, the number of fraudulent events related to fintech lending applications has instilled more fear in the minds of users, thereby increasing user demand for security and e-trust in transactions on their fintech lending applications. So, it can be concluded that e-trust has an influence on attitude. The more trust someone has in the security system offered by an online application, the less afraid he or she will be to use it in their daily activities, including entering their personal data. This is supported by the finding that the majority of respondents considered the use of fintech lending applications a wise idea because the applications were very efficient, reliable, safe to use, and continuously improved according to technological developments and had a concern for consumer problems. This is also supported by the beliefs that fintech lending applications are the best solutions in the industry, good response to consumer needs and ease in making complaints make respondents wish to use the fintech lending application. In addition, design of fintech lending application should easy to understand and can get attention for each user, security features that make a sense of security in storing personal data is considered a pleasant experience.

The results of this study provide valuable insights for fintech lending industry players to be aware of the diversity of attitudes among the target users of fintech lending technology and to adjust their marketing strategies. Professional fintech lending must consider influencing intention to use by not only developing perceived ease of use and perceived usefulness but also promoting professional credibility and integrity of the company.

Because e-trust is the highest concern for fintech lending users, fintech lending companies must also create a communication strategy that seeks to attract users by focusing on company integrity and showing how the safety and security of data has been ensured by fintech lending companies. Companies must work to build a safe and secure reputation and get positive support from the user community through word-of-mouth strategies so that it can optimally increase the perception of e-trust in fintech lending companies, which will improve the perception of potential users about the use of fintech lending applications. This research also suggests that in addition to conventional communication activities, promoting fintech lending products requires the effort of contemporary marketing communication strategies, such as online marketing, e-mail, blogs, and social networking.

\section{Conclusions}

The ability to understand information and the benefits of using online loan applications among target users in Indonesia are still major factors in adopting a new technology at the level of use, so we suggest additional research that is oriented toward users of banking services on the internet, especially peer-to-peer lending fintech application services. By knowing the specific desires of the segments of society studied, the banking industry, particularly digital banking that develops fintech peer-to-peer lending, can focus on understanding and increasing people's desires about what features must be provided to provide banking services and improve operational efficiency.

This study intentionally examined the role of e-trust in the use of peer-to-peer lending fintech applications by banking consumers in Indonesia. It is evident that the etrust dimension contributed to determining the perceived usefulness, perceived ease of use, and attitude to adopt peer-to-peer lending fintech services and the intention to use the peer-to-peer fintech lending applications. In addition, this study also shows the importance of the role of e-trust variables in determining the perceived benefits, 
attitudes toward internet banking, and behavioral intentions. The users' perception that electronic transactions are easy and can be controlled is very important for internet banking business adoption because ease of use and trust creates control and perception of usability.

An implication of this research is the importance of the digital banking industry, especially the fintech peer-to-peer lending application service, owning and developing an internet banking system that is easy to use and has features that suit user needs. Given the large number of resources that have been invested in realizing the internet banking system globally, it is very important to ensure that user will use fintech lending applications. To achieve this goal, special attention is needed to design fintech peer-topeer lending application displays that are easy to use, useful, and reliable. Internet banking industry players need to develop confidence in perceived usefulness, perceived ease of use, user credibility, and integrity regarding fintech peer-to-peer lending applications.

This research still has some limitations and allows for further research. This research is an empirical study conducted with an observational research approach carried out at one time. This results in a lack of ability of the study results to reflect temporal changes in research construction, especially when internet banking technology is changing very rapidly. Future research efforts in the future should also be done to validate intention to use through the actual use of the system.

\section{References}

Aaron, M., Rivadeneyra, F., Sohal, S., 2017. Fintech: Is This Time Different? A Framework for Assessing Risks and Opportunities for Central Banks (No. 2017-10). Bank of Canada. Available Online at https://www.bankofcanada.ca/2017/07/staff-discussion-paper2017-10/, Accessed on August 2, 2018

Accenture., 2019. Future of FinTech and Banking-Accenture. Accenture. Available Online at https://www.accenture.com/sg-en/insight-future-fintech-banking, Accessed on August 4, 2018

Agarwal, R., Rastogi, S., Mehrotra, A., 2009. Customers' Perspectives Regarding e-banking in an Emerging Economy. Journal of Retailing and Consumer Services, Volume 16(5), pp. 340-351

Alalwan, A.A., Baabdullah, A.M., Rana, N.P., Tamilmani, K., Dwivedi, Y.K., 2018. Examining Adoption of Mobile Internet in Saudi Arabia: Extending TAM with Perceived Enjoyment, Innovativeness and Trust. Technology in Society, Volume 55, pp. 100-110

Alalwan, A.A., Dwivedi, Y.K., Rana, N.P., Lal, B., Williams, M.D., 2015. Consumer Adoption of Internet Banking in Jordan: Examining the Role of Hedonic Motivation, Habit, Selfefficacy and Trust. Journal of Financial Services Marketing, Volume 20(2), pp. 145-157

AlphaJWCVentures., 2019. Fintech Indonesia: 8 Popular Fintech Companies. AlphaJWCVentures. Available Online at https://www.alphajwc.com/en/fintechindonesia/, Accessed on August 20, 2018

Alsajjan, B., Dennis, C., 2010. Internet Banking Acceptance Model: Cross-market Examination. Journal of Business Research, Volume 63(9-10), pp. 957-963

Arner, D.W., Barberis, J.N., Buckley, R.P., 2015. The Evolution of Fintech: A New Post-Crisis Paradigm? (SSRN Scholarly Paper ID 2676553). Social Science Research Network

Badan Pusat Statistik, 2018. Available Online at https://www.bps.go.id/publication/2018/10/05/02d80724b71eb684620a2e88/pdb -indonesia-triwulanan-2014-2018, Accessed on October 6, 2018 
Bank Indonesia, 2017. Bank Indonesia Issues Provisions for the Implementation of Financial Technology-Central Bank of the Republic of Indonesia [Bank Indonesia]. Available Online at https://www.bi.go.id/id/ruang-media/siaranpers/Pages/sp_199317.aspx, Accessed on August 20, 2018

Ben Mansour, K., 2016. An analysis of Business' Acceptance of Internet Banking: An Integration of E-trust to the TAM. Journal of Business \& Industrial Marketing, Volume 31(8), pp. 982-994

Berawi, M.A., 2014. Creating Alternatives through Design and Technology Innovation. International Journal of Technology, Volume 5(1), pp. 1-2

Candra, S., 2013. Revisit Technology Acceptance Model for Internet Banking (Case Study: Public Banking in Indonesia). In: International Conference on Computer, Networks and Communication Engineering (ICCNCE 2013)

Cohen, J., 2013. Statistical Power Analysis for the Behavioral Sciences. Routledge, New york https://doi.org/10.4324/9780203771587

Davis, F.D., 1989. Perceived Usefulness, Perceived Ease of Use, and User Acceptance of Information Technology. MIS Quarterly, Volume 13(3), pp. 319-340

Davis, K., Maddock, R., Foo, M., 2017. Catching up with Indonesia's Fintech Industry. Law and Financial Markets Review, Volume 11(1), pp. 33-40

Dipa, M., 2018. Kredivo is on the List of the 100 Most Innovative Fintech Startups in the World. Warta Kota. Available Online at https://wartakota.tribunnews.com/2018/11/24/kredivo-masuk-daftar-100-startuptekfin-paling-inovatif-di-dunia, Accessed on November 24, 2018

Duwitmu, 2019. Review Koinworks, Investree, Amartha | Investasi P2P Lending Terbaik. Duwitmu.Com. Available Online at https://duwitmu.com/investasi/koinworksinvestree-amartha-investasi-p2p-2019/, Accessed on July 1, 2019

Ezzi, S.W., 2014. A Theoretical Model for Internet Banking: Beyond Perceived Usefulness and Ease of Use. Archives of Business Research, Volume 2(2), pp. 31-46

Fishbein, M., Ajzen, I., 1975. Belief, Attitude, Intention, and Behavior: An Introduction to Theory and Research. Addison-Wesley. Available Online at https://people.umass.edu/aizen/f\&a1975.html, Accessed on July 1, 2018

Frame, W.S., White, L.J., 2014. Technological Change, Financial Innovation, and Diffusion in Banking (SSRN Scholarly Paper ID 2380060). Social Science Research Network. Available Online at https://papers.ssrn.com/abstract=2380060, Accessed on August 1, 2018

Franedya, R., 2019. Revealed! GoPay Transaction in 2018 Reached Rp 87 T. CNBC Indonesia. Available Online at https://www.cnbcindonesia.com/tech/20190211103125-3754742/terungkap-transaksi-gopay-di-2018-tembus-rp-87-t, Accessed on July 7, 2019

Gibson, J., 2015. The Impact FinTech is having on the Financial Services Industry in Ireland. Master's Thesis, Graduate Program, Dublin Business School, Irlandia

Giudici, P., 2018. Fintech Risk Management: A Research Challenge for Artificial Intelligence in Finance. Frontiers in Artificial Intelligence, Volume 1, Article 1

Gozali, L., Masrom, M., Zagloel, T.Y.M., Haron, H.N., Garza-Reyes, J.A., Tjahjono, B., Irawan, A. P., Daywin, F.J., Syamas, A.F., Susanto, S., Aliwarga, H.K.K., Marie, I.A., 2020. Performance Factors for Successful Business Incubators in Indonesian Public Universities. International Journal of Technology, Volume 11(1), pp. 156-166

Hadad, M.D., 2017. Financial Technology (FinTech) di Indonesia [Indonesia Banking School]. Kuliah Umum Tentang FinTech - IBS. Available Online at http://www.ibs.ac.id/img/doc/MDH\%20\%20FinTech\%20IBS\%20June\%202017.pdf, Accessed on August 2, 2018 
Hair, J.F., Black, W.C., Babin, B.J., Anderson, R.E., 2010. Multivariate Data Analysis, $7^{\text {th }}$ Edition. Pearson Education, London

Hampshire, C., 2017. A Mixed Methods Empirical Exploration of UK Consumer Perceptions of Trust, Risk and Usefulness of Mobile Payments. International Journal of Bank Marketing, Volume 35(3), pp. 354-369

Jünger, M., Mietzner, M., 2019. Banking Goes Digital: The Adoption of FinTech Services by German Households. Finance Research Letters, Volume 34, https://doi.org/10.1016/j.frl.2019.08.008

Ketterer, J.A., 2017. Digital Finance: New Times, New Challenges, New Opportunities. InterAmerican Development Bank. Available Online at https://publications.iadb.org/en/digital-finance-new-times-new-challenges-newopportunities, Accessed on August 2, 2018

Kock, N., 2010. Using WarpPLS in E-collaboration Studies: An Overview of Five Main Analysis Steps. International Journal of E-Collaboration (IJeC), Volume 6(4), pp. 1-11

KPMG., 2018. The Fintech Edge: Peer-to-peer Lending - KPMG Indonesia. KPMG. Available Online at https://home.kpmg/id/en/home/insights/2018/11/id-the-fintech-edgep2p-lending.html, Accessed on August 20, 2018

Kurniawan, T.A., Wardani, D.K., Widhayati, L., 2019. Pengaruh Keberterimaan Layanan Peer to Peer Lending Kepada UMKM Sebagai Pengguna dengan Menggunakan Metode Technology Acceptance Model (TAM) (The Effect of Acceptance of Peer to Peer Lending Service to MSMEs as Users using the Technology Acceptance Model (TAM) Method). Jurnal Sosial Ekonomi Dan Humaniora, Volume 5(2), pp. 151-160

Lee, M.-C., 2009. Factors Influencing the Adoption of Internet Banking: An Integration of TAM and TPB with Perceived Risk and Perceived Benefit. Electronic Commerce Research and Applications, Volume 8(3), 130-141

Magee, J., 2011. Peer-to-Peer Lending in the United States: Surviving after Dodd-Frank. North Carolina Banking Institute, Volume 15(1), p. 139

Micu, I., Micu, A., 2016. Financial Technology (Fintech) and Its Implementation on the Romanian Non-banking Capital Market. SEA - Practical Application of Science, Volume 11, pp. 379-384

Nui Polatoglu, V., Ekin, S., 2001. An Empirical Investigation of the Turkish consumers' Acceptance of Internet Banking Services. International Journal of Bank Marketing, Volume 19(4), pp. 156-165

Nursyirwan, A.S., 2018. Kemudahan Jadi Alasan Masyarakat Meminjam Lewat Fintech (Ease is the Reason People Borrow Through Fintech). Antara News. Available Online at https://www.antaranews.com/berita/741266/kemudahan-jadi-alasan-masyarakatmeminjam-lewat-fintech, Accessed on August 20, 2018

Otoritas Jasa Keuangan, 2017. Fintech Statistic. Available Online at https://www.ojk.go.id/id/kanal/iknb/data-dan-statistik/fintech/Default.aspx, Accessed on August 3, 2018

Otoritas Jasa Keuangan, 2019. Penyelenggara Fintech Terdaftar dan Berizin di OJK per 7 Agustus 2019 (Fintech Providers Registered and Licensed at OJK as of August 7, 2019). Otoritas Jasa Keuangan. Available Online at https://www.ojk.go.id/id/berita-dankegiatan/publikasi/Pages/Penyelenggara-Fintech-Terdaftar-dan-Berizin-di-OJK-per7-Agustus-2019.aspx, Accessed on August 9, 2019

Prawirasasra, K.P., 2018. Financial Technology in Indonesia: Disruptive or Collaborative? Reports on Economics and Finance, Volume 4(2), pp. 83-90

Prayogo, H.S., 2017. Ini Dia Peraih Indonesia Digital Innovation Award 2017 (Here is the Indonesian Digital Innovation Award Winner). Warta Ekonomi. Available Online at 
https://www.wartaekonomi.co.id/read144717/ini-dia-peraih-indonesia-digitalinnovation-award-2017, Accessed on August 2, 2018

Santoso, H., Abdinagoro, S.B., Arief, M., 2019. The Role of Digital Literacy in Supporting Performance Through Innovative Work Behavior: The Case of Indonesia's Telecommunications Industry. International Journal of Technology, Volume 10(8), pp. 1558-1566

Schueffel, P., 2016. Taming the Beast: A Scientific Definition of Fintech. Journal of Innovation Management, Volume 4(4), pp. 32-54

Sekaran, U., Bougie, R., 2016. Research Methods For Business: A Skill Building Approach, $7^{\text {th }}$ Edition. Wiley. Available Online at https://www.wiley.com/enid/Research+Methods+For+Business $\% 3 \mathrm{~A}+\mathrm{A}+$ Skill+Building+Approach $\% 2 \mathrm{C}+7 \mathrm{th}+\mathrm{Edit}$ ion-p-9781119266846, Accessed on August 2, 2018

Setyowati, D., 2019. Riset: Kalahkan OVO, GoPay Paling Banyak Digunakan Tahun Ini Katadata.co.id. (Research: Defeat OVO, GoPay Most Used This Year - Katadata.co.id.) Available Online at https://katadata.co.id/berita/2019/11/27/riset-kalahkan-ovogopay-paling-banyak-digunakan-tahun-ini, Accessed on November 27, 2019

Sjamsudin, S.H., 2019. The Impact of the Development of Fintech on the Existing Financial Services in Indonesia. International Journal of Advanced Research in Technology and Innovation, Volume 1(1), pp. 14-23

Smith, D.A., Langfield-Smith, K.M., 2004. Structural Equation Modeling in Management Accounting Research: Critical Analysis and Opportunities. Journal of Accounting Literature, Volume 23, pp. 49-86

Sun, J., Chi, T., 2019. Investigating the Adoption of Apparel m-commerce in the US Market. International Journal of Clothing Science and Technology, Voluem 31(4), pp. 544-563

Suyanto, S., Kurniawan, T.A., 2019. Faktor yang Mempengaruhi Tingkat Kepercayaan Penggunaan FinTech pada UMKM dengan Menggunakan Technology Acceptance Model (TAM) (Factors Affecting the Level of Trust in the Use of FinTech in MSMEs using the Technology Acceptance Model (TAM)). AKMENIKA, Volume 16(1), Article 1

Taylor, S., Todd, P.A., 1995. Understanding Information Technology Usage: A Test of Competing Models. Information Systems Research, Volume 6(2), pp. 144-176

Temelkov, Z., 2018. Fintech Firms Opportunity or Threat for Banks? International Journal of Information, Business and Management, Volume 10(1), pp. 138-144

Triandis, H.C., 1980. Values, Attitudes, and Interpersonal Behavior. Nebraska Symposium on Motivation. Nebraska Symposium on Motivation, Volume 27, pp. 195-259

Venkatesh, V., Davis, F.D., 1996. A Model of the Antecedents of Perceived Ease of Use: Development and Test. Decision Sciences, Volume 27(3), pp. 451-481

Wang, Y.D., Emurian, H.H., 2005. An Overview of Online Trust: Concepts, Elements, and Implications. Computers in Human Behavior, Volume 21(1), pp. 105-125

Xie, P., Zou, C., Liu, H., 2016. The Fundamentals of Internet Finance and Its Policy Implications in China. China Economic Journal, Volume 9(3), pp. 240-252

Zhou, T., 2011. Examining the Critical Success Factors of Mobile Website Adoption. Online Information Review, Volume 35(4), pp. 636-652 